\title{
OPENING NEIGHBOURHOOD STREETS FOR CHILDREN'S OUTDOOR FREE PLAY AND COMMUNITY BUILDING
}

\author{
by \\ Zainab Aamir Abbasi
}

BA Hons., University of Toronto, 2016

A Major Research Paper

presented to Ryerson University

in partial fulfillment of the requirements for the degree of

Master of Planning

in

Urban Development

- Toronto, Ontario, Canada, 2018* 


\section{OPENING NEIGHBOURHOOD STREETS FOR COMMUNITY-BUILDING AND CHILDREN'S OUTDOOR FREE PLAY}

\section{Author's Declaration for Electronic Submission of a MRP}

I hereby declare that I am the sole author of this MRP. This is a true copy of the MRP, including any required final revisions.

I authorize Ryerson University to lend this MRP to other institutions or individuals for the purpose of scholarly research.

I further authorize Ryerson University to reproduce this MRP by photocopying or by other means, in total or in part, at the request of other institutions or individuals for the purpose of scholarly research.

I understand that my MRP may be made electronically available to the public. 
OPENING NEIGHBOURHOOD STREETS FOR COMMUNITY-BUILDING AND

CHILDREN'S OUTDOOR FREE PLAY

\title{
OPENING NEIGHBOURHOOD STREETS FOR COMMUNITY-BUILDING AND
} CHILDREN'S OUTDOOR FREE PLAY

\author{
(C) Zainab Aamir Abbasi, 2018 \\ Master of Planning \\ in \\ Urban Development \\ Ryerson University
}

\begin{abstract}
Street play interventions have the potential to socially benefit children and all community members within a neighbourhood, which have increasingly been taken over by vehicles. The StreetPLAY pilot program implemented in the city of Toronto by Earth Day Canada is the firstof-its-kind in Canada. Surveys in the neighbourhood were analyzed to explore the social benefits, associations between demographics and perceptions, and potential for replication in similar urban neighbourhood contexts. The results from independent sample t-tests and ANOVA tests indicate community member's age and status as a parent was statistically significant to perceptions of community connectivity following StreetPLAY programming. The findings from this research confirm the social benefits to the community and contribute to novel Canadian research on play interventions; they are a quick and inexpensive form of tactical urbanism programming to create opportunities for children's outdoor free play and community gathering.

Key words:

Outdoor play, streets as public space; tactical urbanism; community building, health and wellbeing
\end{abstract}

\section{School of Urban \& Regional Planning 18}




\section{OPENING NEIGHBOURHOOD STREETS FOR COMMUNITY-BUILDING AND CHILDREN'S OUTDOOR FREE PLAY}

\section{Acknowledgements}

I would like to thank my professor and first reader, Dr. Raktim Mitra at the School of Urban and Regional Planning. This research endeavour would not have been possible without the incredible support, patience and valuable guidance I have received from him.

Many thanks are due to my second reader, Dr. Pamela Robinson at the School of Urban and Regional Planning for her time and support.

I would like to thank Earth Day Canada for allowing me to collect data on their StreetPLAY pilot program and for financially supporting the program research. I am also appreciative of the local community members, who contributed their time to volunteer on their street and support the play event programming, which created the opportunity for children to roam freely on the street and for neighbours to bond on their front porches, even if only for a few hours.

Finally, I would like to express my profound gratitude to my parents, and to my fiancé for their gracious support, patience and unwavering encouragement throughout my master's degree and the writing of this research paper. They are my support system without whom this accomplishment would not have been possible. Thank you. 
OPENING NEIGHBOURHOOD STREETS FOR COMMUNITY-BUILDING AND CHILDREN'S OUTDOOR FREE PLAY

Table of Contents

Chapter

1. Introduction.

Page

2. Literature Review...........................................................

3. Research Methodology .........................................................9

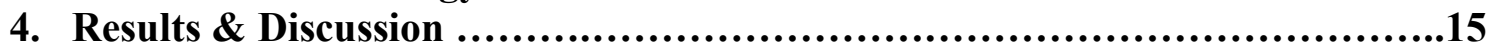

5. Implications and Conclusion................................................24

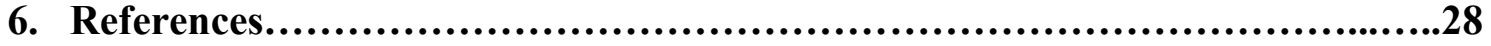




\section{List of Tables \& Figures}

List of Tables

1. StreetPLAY Pilot Program weekly schedule of events.

2. Factor loadings based on a factor analysis with promax rotation for 8 items from the neighbourhood survey perception questions $(n=105) \ldots \ldots \ldots . .13$

3. Summary statistics of parents and caregiver's demographics from

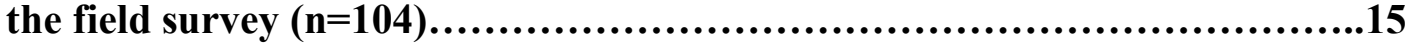

4. Summary statistics of children's demographics and participation at StreetPLAY from the field survey $(n=158)$.

5. Summary statistics of activities children participated in at StreetPLAY

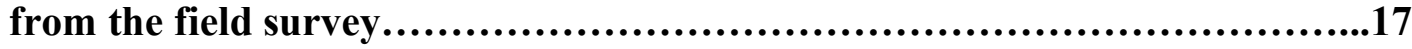

6. Summary statistics of demographics from the neighbourhood survey $(n=105)$

7. Summary statistics of community member's perceptions from the neighbourhood survey $(n=105)$

8. Summary of results from independent sample t-test and ANOVA tests to analyze potential impact of demographics on community member's perception on community connectivity.

9. Summary of results from independent sample t-test and ANOVA tests to analyze potential impact of demographics on community member's perception on children's social capital.

List of Figures

1. Map of Seaton Village, Toronto, Ontario: StreetPLAY Pilot program street sections. 


\section{OPENING NEIGHBOURHOOD STREETS FOR COMMUNITY-BUILDING AND CHILDREN'S OUTDOOR FREE PLAY}

\section{Chapter 1: Introduction}

Children today have been deprived of the opportunity to engage in play (Jarvis, Newman \& Swiniarski, 2014). Historically common places for children to play outdoors, in recent years streets have been taken over by vehicles, and as a result, adults have discouraged children's presence on their neighbourhood streets. In addition, cultural changes such as an increased expectation of adult supervision and parental concerns over safety from traffic have severely limited children from playing freely on their streets (Faulkner et al., 2015; Carver et al., 2008). As a response to their concerns, parents have increasingly placed children in organized sports and programmed extracurricular activities in place of free play which have reduced the possibilities for creativity and imagination in free play (Read, 2011). These cultural changes, coupled with regulatory mechanisms employed to separate land uses, and a lack of access to playgrounds and open spaces have engineered children out of the streets (Read, 2011; Hart, 2002; Faulkner et al., 2015; Carver et al., 2008) and have limited children to the confines of their homes to play freely (Tandy, 1999; Karsten, 2005; Carver et al., 2008). Re-introducing urban and suburban neighbourhood streets for children's outdoor play can be a way of providing easy access to play space for a vast majority of our children.

Outdoor free play carries immense physical, health and social benefits for children (Valentine \& McKendrick, 1997; Cheng \& Johnson, 2010; Gleave \& Cole-Hamilton, 2012; Faulkner et al, 2015). Creating opportunities for children to play on their neighbourhood streets is an inexpensive way to encourage more physical activity and help children benefit physically and socially close to home (Humbert et at., 2006). This research is premised on the belief that play is critical not only to the social health of children, but it also provides an opportunity for

parents and community members to interact with one another, develop a sense of community and build social capital (Murray \& Devecchi, 2016; Wilson, 1996; Weller and Bruegel, 2009; Offer and Schneider, 2007). These benefits to community members will be explored in this study, using data collected from a play intervention program called StreetPLAY, which was piloted in the City of Toronto, Canada, in the summer and fall of 2017.

Re-introducing streets as spaces for children's outdoor free play has become almost impossible without some form of programmed intervention. These interventions, known broadly as "tactical urbanism" in the field of Urban Planning, are citizen-organized, quick and inexpensive tactics to improve the local environment as a response to the lengthy bureaucratic 


\section{OPENING NEIGHBOURHOOD STREETS FOR COMMUNITY-BUILDING AND CHILDREN'S OUTDOOR FREE PLAY}

process of implementing changes in the local environment (Lydon \& Garcia, 2015). Where broader policies do not support such opportunities for play, citizens may mobilize in reimagining, reclaiming and reprogramming public spaces and demonstrating the effects of short term actions on long term changes in improving livability and building social capital (Lydon \& Garcia, 2015). Citizen-initiated interventions at the neighbourhood level such as park(ing) daytemporarily turning parking spaces into independent parks for a day, open streets and cicloviasclosing streets to vehicles and transforming them into open spaces for play and active transportation (D'Haese et al., 2015), engage citizens as active players in planning their urban environments, rather than as passive consumers (Coombs, 2012). They incite citizens in a form of community-centric, collaborative planning to help reframe common conceptions of public space, its users and how it can be used (Coombs, 2012). From the get-go the aim of these tactics and short term interventions is to bring attention to the benefits of them to citizens and garner wider popular and municipal policy support.

The lack of policy support in Toronto and elsewhere in North America can be seen as a missed opportunity for integrating children's needs and access to streets and public space into planning practice. However, "street play" interventions, which are community-driven programming that broadly follow tactical urbanism principles, have recently been introduced in a few western cities; the first street play event in the USA was hosted by New York City in 2012 (Murray \& Devecchi, 2016; Zeif, Chaudhuri \& Musselman, 2016). There has been a resurgence of street play events across North America and Europe in recent years in efforts to welcome children onto the street again. Although such play interventions are now emerging in these communities, there is a lack of, and critical need for systematic evaluations of the benefits of these events to the community- in addition to the well-documented physical health benefits it has for children. More specifically, the current pilot programs require further exploration to identify the exact ways in which communities can socially benefit, and to identify ways to foster an inclusive play environment for all members of the community.

The case of Toronto is similar to other western cities where vehicles dominate the streets, and until very recently, children were not allowed to play on their local streets due to policy measures in place, namely a "street hockey ban". The street hockey ban in the City of Toronto was lifted in 2016 and opened up the opportunity for neighbourhood streets for outdoor play (City of Toronto By-law Number 775-2016). However, to temporarily program neighbourhood 


\section{OPENING NEIGHBOURHOOD STREETS FOR COMMUNITY-BUILDING AND CHILDREN'S OUTDOOR FREE PLAY}

streets for any community use a street, closure permit needs to be obtained which is a time consuming and expensive process. The street closure permit process may be inaccessible to many communities due to the high cost. The permit process also limits communities from participating where there is a lack of political interest or support for such play events which makes it more difficult or impossible to obtain a permit for street play events.

Earth Day Canada, a non-profit organization in the city of Toronto co-organized with city councilors and the city of Toronto to obtain permits for street closures to test out a pilot programming, StreetPLAY, to encourage play on local neighbourhood streets. The programming was implemented in summer and fall of 2017 in the Seaton Village neighbourhood, an innerurban neighbourhood within the City of Toronto. TransForm Laboratory out of Ryerson University conducted an independent evaluation of the pilot program to explore potential benefits at the community level.

Using the dataset of surveys collected, this MRP study explores the perceived social benefits of participating in children's street play interventions for community members. First, this study will explore the social benefits of StreetPLAY to children for whom the play intervention is targeted at. The study explores whether StreetPLAY increased opportunities for children's play and for children to socially interact and make friends. Second, the study will then explore the benefits of the programming to the community, as well as if perception of these benefits varied across socio-demographic groups within the neighbourhood.

The findings will contribute to emerging literature on the social impacts of such play interventions to communities in the North American context and will help inform the development of strategies that can be implemented to foster a more inclusive, engaging street play environment for all community members to participate in. It is important to explore the impacts of the programming on community members and the potential to replicate such play interventions in similar inner-urban neighbourhood settings across the Western world where streets can be shared more equitably among all road users. 


\section{OPENING NEIGHBOURHOOD STREETS FOR COMMUNITY-BUILDING AND CHILDREN'S OUTDOOR FREE PLAY}

\section{Chapter 2: Literature Review}

\section{Benefits of Outdoor Play}

Undirected outdoor free play where children independently explore and choose their activities, is a natural and necessary activity for children (Louv, 2005; Moyles, 2015). It is an immense development opportunity that is well-documented in helping children develop physical, mental, social and creative capabilities (Valentine \& McKendrick, 1997; Cheng \& Johnson, 2010; Gleave \& Cole-Hamilton, 2012).

In Europe, research over 40 years has shown that schools only account for between 20 $40 \%$ of children's learning outcomes (skills, knowledge and attitudes) achieved by students (Kellock, 2015). Play provides learning opportunities that cannot be replaced by academic learning opportunities. Play carries many social benefits as well, as it helps children learn to share, to communicate, negotiate and work in teams (Ginsburg, 2007).

Spending time outdoors has been associated with greater physical activity for children (Klesges et al., 1990; Sallis et al., 1993; D’Haese, 2015; Faulkner et al., 2015). The physical activity benefits that play offers has made it a greater area of concern of public health policy in recent years to encourage opportunities for children to play (Canadian Society for Exercise Physiology, 2011). Previous research supports this as it suggests that children who spend more time playing outdoors than indoors are more active (Cooper et al., 2010), and yet, only 47\% of grade 5/6 children in Toronto spent less than an hour playing outdoors in a typical weekday (Faulkner et al., 2015). Play participation among younger children may be even less. Low participation in play is a missed opportunity for physical activity accumulation, which is important for children's health and wellbeing. More importantly, encouraging children to play outdoors can help them become more active as they grow up (Page et al. 2009, 2010; ParticipACTION, 2015). Increasing the opportunities to accumulate physical activity also helps children curb major health risks such as obesity and hypertension (Guillaume, 1997; Frederick et al, 2014). The effects may be even more pronounced in children of lower socioeconomic status where children may face greater neighbourhood barriers such as lack of access to play places (Ding et al, 2011; Ravensbergen et al, 2016). Poor neighbourhood design with lack of access to open spaces and parks may also limit the opportunities for physical activity and outdoor play (Floyd et al, 2011). Similarly, a recent study of grade 5 and 6 school children in the City of Toronto found differences in physical activity participation between children in inner-urban and 


\section{OPENING NEIGHBOURHOOD STREETS FOR COMMUNITY-BUILDING AND CHILDREN'S OUTDOOR FREE PLAY}

suburban neighbourhoods (Cantello, Mitra \& Buliung, 2016) which highlights the impact of geographical and build environment differences in influences children's participation.

More broadly, play interventions may offer an opportunity for social interaction among children and community members outside their front door to ultimately build their social capital. Social capital is the potential in social ties and networks to enable community members to organize and achieve shared visions (Semenza \& March, 2008). These social capital building opportunities within the community are encompassed in the metrics used to measure wellbeing in the Canadian Index of Wellbeing, thus indicating that social capital contributes to overall wellbeing. The Canadian Index of Wellbeing emphasizes the quality and perception of various social aspects to measure wellbeing. For example, how much time people are spending with their friends and within community, sense of community belonging, and how safe they feel in their neighbourhoods are outlined as some indicators of wellbeing (Michalos et al., 2011; Smale, 2010; Canadian Index of Wellbeing, 2016). Such indicators can be utilized to examine the community-level benefits and improved social capital of StreetPLAY.

\section{Parental and community perceptions on children's outdoor play}

Parents and caregivers, and more broadly the social norms around child supervision, perform an important role and impact the opportunities for play children partake in, and the duration of children's outdoor play (Faulkner et al., 2015). Particularly, adult concerns for safety from traffic and strangers reduces opportunities for children's outdoor play (Faulkner et al., 2015; Murray \& Devecchi, 2016; Valentine and McKendrick, 1997; Burdette \& Whitaker, 2005). These perceptions serve as barriers preventing children from freely engaging in outdoor play. For example, parents' concern over child pedestrian injuries may lead them to change their routines and activities to avoid chances for child pedestrian injuries (Timperio et al., 2004). Dedicating attention to awareness and shifting the social norms will be important to overcoming these barriers and re-introducing public spaces and streets for children's outdoor play. This shifting of social norms to reclaim streets may take the form of temporary changes to experiment with the street for play or engaging with city professionals to bring formal policy and regulatory changes (Fotel, 2009). Parents need to be actively involved in order to overcome these barriers (Ginsburg, 2007). 


\section{OPENING NEIGHBOURHOOD STREETS FOR COMMUNITY-BUILDING AND CHILDREN'S OUTDOOR FREE PLAY}

\section{Bringing Back Play to the Streets}

(Re)allowing play in urban and suburban neighbourhood streets can be a way of providing easy access to play space for a vast majority of our children who have been deprived of the opportunity to play (Jarvis, Newman \& Swiniarski, 2014). Since the mid-1900s, regulatory mechanisms used to separate land uses, the push towards organized and supervised activities and prevalence of the automobile have engineered children out of the streets (Read, 2011; Hart, 2002). These changes were accompanied by the cultural shift which perceived street or gutter play as leading to 'inappropriate behaviour' (Hart, 2002) and thus deemed undesirable. Activities such as playing with dirt have been replaced with sand pit play and gardening (Hart, 2002). In England, for example, gutter play was replaced with 'Free Kindergartens' because it embodied less risk and offered gardens as a safe supervised play space. Free Kindergartens were premised on teaching children appropriate behaviour and socialization, as playing on the streets was considered to promote poor behaviour (Read, 2011). Around the same time, in the United States, playgrounds were being used to steer children away from playing on the streets and into controlled spaces where behaviour could be monitored closely and 'appropriate' play would occur (Hart, 2002). More than ever before, children were being kept out of our streets through mechanisms such as the play bans. More importantly, they are often made to feel marginalized around vehicles on streets (Fotel, 2009). One study on 11- and 12-year-old Danish children (Fotel, 2009) found the children did not feel respected by car drivers even when they had the right of way. These cultural shifts overtime demonstrate the complexities and challenges children face today in accessing streets for play or active transportation.

The concept of 'third place' (Oldenburg, 1989, 2001) aids in the understanding of informal spaces which are crucial to socializing and play, outside of the home (first place) or school or work (second place). These third places can be local parks, shops or transitional zones like streets where everyone feels welcome and is a regular user of the space (Witten et al., 2015). The changing function of local neighbourhood streets as primarily for vehicular traffic (Veitch et al., 2006) limits the use of the 'third spaces' for children's outdoor free play.

In most urban neighbourhoods that are interspersed and well-serviced by streets, streets can be a place to play outside for children who lack easy access to local parks or do not live near local parks (Veitch et al, 2007). Neighbourhood streets are also an inexpensive option to participate in play, which makes play more accessible in low income neighbourhoods (Humbert 


\section{OPENING NEIGHBOURHOOD STREETS FOR COMMUNITY-BUILDING AND CHILDREN'S OUTDOOR FREE PLAY}

et al., 2006). It cuts down on transportation costs, fees for programmed sports and extracurricular activities, and supervision of children may be shared among neighbours or family members who may supervise from the front porch.

\section{The Street Hockey and Ball Play Ban in Toronto}

The City of Toronto, like other municipalities in Ontario such as Hamilton and Kingston, banned Street Hockey and Ball Play on streets under the City of Toronto Act in 2006; a key purpose of this ban was to maintain streets for the safe passage of vehicular and pedestrian traffic (City of Toronto, 2011; 2016). The ban was also placed to ensure the safety of children who may be less aware of their surroundings when parents or supervisors are not watching them. Leaving hockey nets or basketballs on the street would result in a $\$ 90$ fine under the ban (City of Toronto, 2011). The ban prevented the opportunity for children to take advantage of local streets as play spaces in close proximity of their homes, where parents or guardians are within earshot distance.

In 2008, the city of Kingston was one of the first municipalities in Ontario to lift the ban on street hockey (City of Kingston By-law Number 2004-190; 2008-144). Under the current bylaw, children can participate in street hockey play as long as they take place during daylight hours in areas where there is a clear view of vehicles approaching, provided that the children have parent or guardian consent to play outside. The framework makes way for children's street hockey play while placing a responsibility on families to have a level of accountability in the play. Recently in 2016, the City of Toronto passed a motion to lift the ban and welcomed the use of local streets for outdoor play (City of Toronto By-law Number 775-2016). This offered an exciting opportunity to welcome children out onto the street for play once again.

\section{Play Interventions from Around the World}

On-street play interventions have been implemented in some other American and European cities in recent years. One of the earliest examples is the Playing Out model from Bristol, UK which was developed by local parents frustrated with the lack of opportunities for children to play freely on the street (Ferguson \& Page, 2015). The low-cost intervention was developed to provide safe spaces for children's free play. It consists of a partial road closure after school hours on designated days for a given period of time, organized and supervised by neighbours. 


\section{OPENING NEIGHBOURHOOD STREETS FOR COMMUNITY-BUILDING AND CHILDREN'S OUTDOOR FREE PLAY}

There are some examples in New York City, USA which were organized through the collaborative efforts of community organizations, non-profit organizations and local governments. Several approaches were tested as pilot programs from one season to two years, such as the Streets Renaissance Program and resulted in long term formalized programming in recent years (Kaboom, 2008). Similar play interventions piloted in Seattle have led to a formalized program managed by the municipal transportation department, complete with tools and resources to equip interested communities with all the information they need to successfully host Play Streets events (Seattle Department of Transportation, 2017).

As part of a national Play Streets program in the United States run by the Partnership for a Healthier America and Blue Cross and Blue Shield Association, play streets programs were implemented in ten cities and some city-wide programs were rolled out as a result (Zieff et al., 2016). Systematic evaluation of the benefits of these programs, however, are scarce. From one of the programs in San Francisco, a study found there was strong agreement throughout the neighbourhood that the program strengthened the community (Zieff et al, 2016). In addition to increasing the physical activity levels, adults engaged with their neighbours during the play events. Based on the play interventions beginning to be implemented thus far, there is growing interest from local governments towards this type of play programming. Findings from this study would further facilitate this emerging process in the Western world and perhaps even enable wider implementation of such play programs. 


\section{OPENING NEIGHBOURHOOD STREETS FOR COMMUNITY-BUILDING AND CHILDREN'S OUTDOOR FREE PLAY}

\section{Chapter 3: Study Design}

\section{Case Study Area}

Earth Day Canada, a non-profit organization based in Toronto collaborated with the City of Toronto's Transportation Services Division to introduce StreetPLAY pilot programming onto residential streets in Toronto. The pilot program took place in Seaton Village, where there were working relationships with the local city councilor and greater political leadership, as well as interested community members. Working with the local communities, Earth Day Canada organized events in the Seaton Village.

The Seaton Village neighbourhood, in the Annex, is an inner-urban neighbourhood in Toronto located north-west of the downtown core, minutes from the main Bloor-Danforth TTC subway line which connects Toronto east to west. The neighbourhood has a higher income than the city of Toronto average (City of Toronto, 2011). In households with children, the majority of children are 14 years old and under (City of Toronto Social Policy Analysis \& Research 2011). The streets in Seaton Village where the StreetPlay project is being piloted are primarily lined by detached, semi-detached and row houses which have appreciated by $62 \%$ in terms of property values, in a short span of 2 years (Metro news 2017).

Seven residential street sections were selected: 4 sections of Clinton Street between Bloor St \& Dupont St; Palmerston Gardens; Markham St \& Follis Ave and; Pendrith Street (see Figure 1). Each day of the week, one or two different streets were closed to vehicles and activated for children's street play (see Table 1). On weekdays, the street closure was from 4-8pm and on Sundays from 2-5pm. A total of 155 StreetPLAY events took place in June, September and October 2017 (Earth Day Canada, 2018).

Parents and community members were recruited to supervise the street closures. Earth Day Canada's Street team and local volunteers (often parents or high school students) supervised the events and managed the street closure during the StreetPLAY events. Locally available materials such as recycling bins and hockey nets with a StreetPLAY sign attached were used as a physical barrier to close off the street to vehicular traffic, except for residents living on the street. 


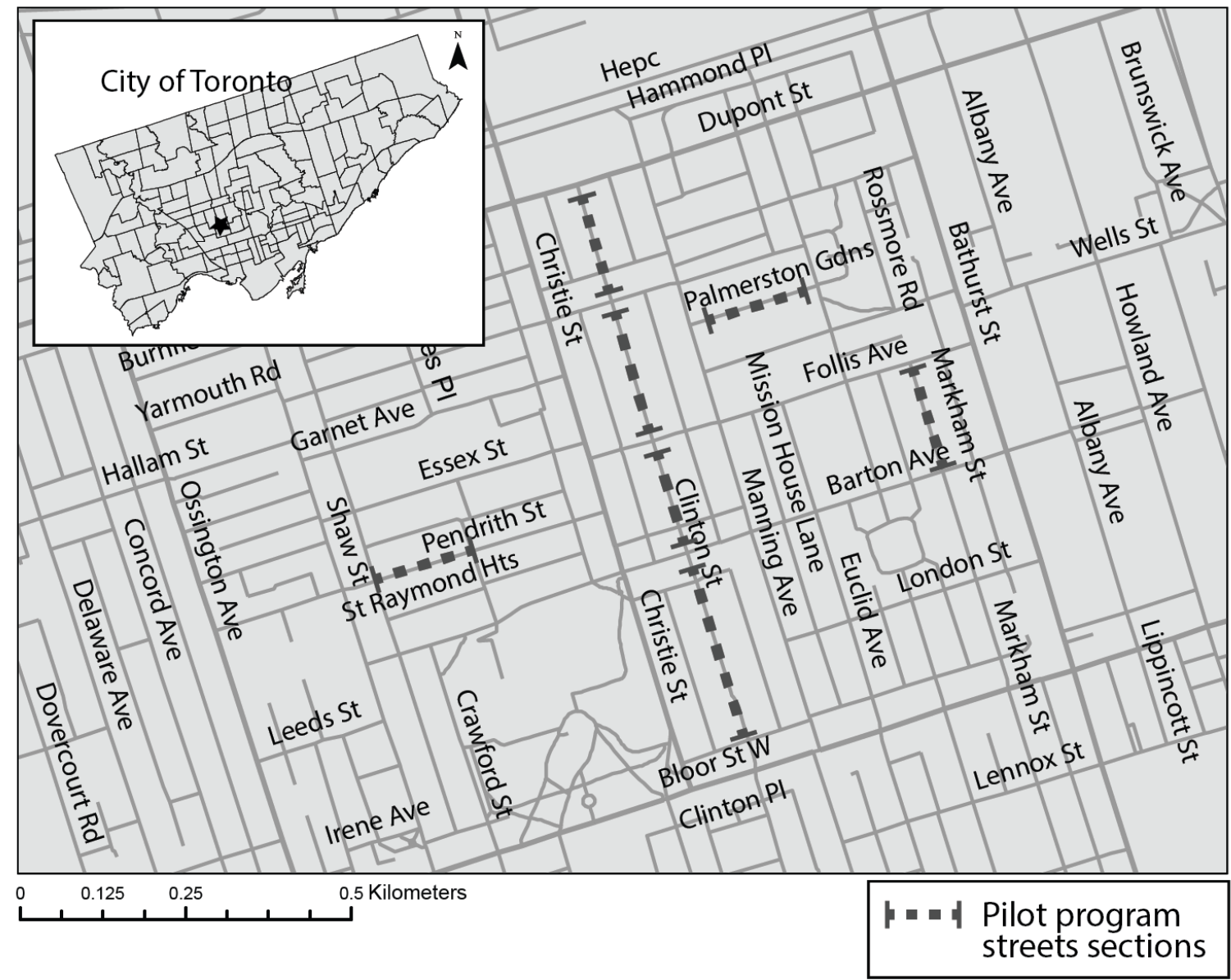

Figure 1. Map of Seaton Village, Toronto, Ontario: StreetPLAY Pilot program street sections

Table 1. StreetPLAY Pilot Program weekly schedule of events.

\begin{tabular}{|c|c|c|c|c|c|}
\hline Sunday & Monday & Tuesday & Wednesday & Thursday & Friday \\
\hline $\begin{array}{l}\text { Clinton } \\
\text { (Barton to } \\
\text { Follis) 2-5pm } \\
\text { Clinton } \\
\text { (laneway to } \\
\text { Barton) 5-8pm } \\
\text { Palmerston } \\
\text { Gardens 4- } \\
\text { 8pm } \\
\text { Markham } \\
\text { Follis 4-8pm }\end{array}$ & $\begin{array}{l}\text { Clinton } \\
\text { (Yarmouth to } \\
\text { Dupont) 4- } \\
\text { 8pm }\end{array}$ & $\begin{array}{l}\text { Pendrith St 4- } \\
8 \mathrm{pm}\end{array}$ & $\begin{array}{l}\text { Clinton (Follis } \\
\text { to Yarmouth) } \\
\text { 4-8pm }\end{array}$ & $\begin{array}{l}\text { Palmerston } \\
\text { Gardens 4- } \\
8 \text { pm }\end{array}$ & $\begin{array}{l}\text { Clinton } \\
\text { (Yarmouth to } \\
\text { Dupont) 4- } \\
\text { 8pm }\end{array}$ \\
\hline
\end{tabular}




\section{OPENING NEIGHBOURHOOD STREETS FOR COMMUNITY-BUILDING AND}

CHILDREN'S OUTDOOR FREE PLAY

\begin{tabular}{|c|c|c|c|c|c|}
\hline $\begin{array}{l}\text { Clinton } \\
\text { (Barton to } \\
\text { Follis) 2-5pm } \\
\text { Clinton } \\
\text { (laneway to } \\
\text { Barton) 5-8pm } \\
\text { Palmerston } \\
\text { Gardens 4- } \\
\text { 8pm }\end{array}$ & $\begin{array}{l}\text { Clinton } \\
\text { (Yarmouth to } \\
\text { Dupont) 4- } \\
\text { 8pm }\end{array}$ & $\begin{array}{l}\text { Pendrith St 4- } \\
8 \mathrm{pm}\end{array}$ & $\begin{array}{l}\text { Clinton (Follis } \\
\text { to Yarmouth) } \\
\text { 4-8pm }\end{array}$ & $\begin{array}{l}\text { Palmerston } \\
\text { Gardens 4- } \\
8 p m\end{array}$ & $\begin{array}{l}\text { Clinton } \\
\text { (Yarmouth to } \\
\text { Dupont) 4- } \\
\text { 8pm } \\
\text { Markham \& } \\
\text { Follis 5-8pm }\end{array}$ \\
\hline
\end{tabular}

\section{Data}

Parents and caregivers of participating children, and community members living on the streets where the pilot programming took place, were surveyed in order to explore their participation, experiences and perceptions of the StreetPLAY pilot and understand who might have benefited or have been affected by the programming. As part of the StreetPLAY pilot program evaluation, we conducted two surveys; the field surveys with parents and caregivers of participating children; and the neighbourhood surveys with all community members. We also conducted systematic field observations to observe the play activities children participated in. In this study, we are using both surveys; the field survey to explore the social benefits of the programming to children and; the neighbourhood survey primarily to explore the social benefits of this type of play intervention on community members. Research ethics approval was obtained from the Ryerson University Research Ethics Board (REB).

\section{Field Surveys}

Field surveys were conducted among parents and caregivers of children participating in the StreetPLAY program. Surveys were conducted at each participating StreetPLAY street on three randomly selected event days at each location, in July, September and October 2017 (two weekdays and a Sunday). A convenience sampling method was used to recruit parents for the field surveys. The survey included 19 questions and took approximately 7 minutes to complete. Surveys were collected by approaching parents at StreetPLAY. In addition, we approached every household (on both sides of the pilot streets) to reach parents who were not on the street to supervise their children participating in the StreetPLAY program. For households with more than one child who participated in StreetPLAY, parents and caregivers were asked to complete a 


\section{OPENING NEIGHBOURHOOD STREETS FOR COMMUNITY-BUILDING AND CHILDREN'S OUTDOOR FREE PLAY}

separate survey for each child, or clearly indicate the different responses for each child on the single survey. We collected 104 responses from parents and caregivers, representing 157 children.

\section{Field Observations}

Systematic field observations were conducted at the StreetPLAY events to observe the range of activities children were participating in, to supplement field survey responses. At each event location, an observation of children's activities were conducted at the beginning of the event, and 1 hour into the StreetPLAY event. This approach was repeated on each of the three days when data was collected. Where children's activities did not have a particular name, the more fitting description of the activity was recorded to capture the nature of the free play activities.

\section{Neighbourhood Surveys}

Neighbourhood surveys were conducted after the completion of the StreetPLAY pilot program, among community members, regardless of whether they or their children had participated in the StreetPLAY event or not. The aim of the neighbourhood surveys was to understand their perceptions towards the StreetPLAY pilot program. The surveys were collected in November 2017 in each participating StreetPLAY neighbourhood on two randomly selected weekday evenings. Each address on both sides of the streets $(n=545)$ was tried at least twice, on different days. One adult household member was asked to fill out the survey, which took approximately 5 minutes to complete. For households with more than one child who participated in StreetPLAY, parents and caregivers were asked to complete the survey where answers would be relevant to only their youngest child.

In order to assess the broader implications of the StreetPLAY pilot programming on the local community, the neighbourhood survey asked a set of 8 questions that aimed to capture the community's perceptions of the social benefits of the programming. Similar to other studies which evaluated the social benefit of interventions at the community level by analyzing social interactions within the community (Semenza \& March, 2008; Zieff et al., 2016), this study analyzed the social benefit based on three dimensions. These questions covered three broad dimensions of benefits: (1) sense of community, (2) citizenship and belonging, and (3)

perceptions on safety. The community members responded to a group of statements on a 5-point Likert scale ranging from 'strongly disagree' to 'strongly agree', re-coded for statistical analysis 


\section{OPENING NEIGHBOURHOOD STREETS FOR COMMUNITY-BUILDING AND CHILDREN'S OUTDOOR FREE PLAY}

from 1 to 5 respectively. We collected 105 responses from community members, at a response rate of $19.3 \%$.

\section{Statistical Analysis}

A series of statistical analysis was conducted to identify correlations between perceptions of StreetPLAY program and various demographic characteristics of the respondents. In order to explore the social benefit of the play intervention to children and community members, the perception questions had to be reduced into key interpretable themes. Factor analysis was used for data reduction, to reduce the amount of data from the 8 perception questions into two key underlying factors which would be easier to indicate the social benefit. The 8 perception questions were of related themes and the factor analysis grouped perception questions which had similar patterns in responses into one theme. The data was reduced into two factors, using a promax rotation which explained $70 \%$ of variations in the dataset (Table 2 ). The first factor (community connectivity) encompassed the following themes: socializing with neighbours; making new friends; community connectivity; participation in and organizing of community events and; mixed age and background interaction. The second factor (children's social capital) encompassed the following themes: that StreetPLAY offered safe outdoor play; required less supervision and; allowed children to make new friends, and each individual was assigned two new factor scores, one for each factor, based on their responses to these 8 questions.

Table 2. Factor loadings based on a factor analysis with promax rotation for 8 items from the neighbourhood survey perception questions $(n=105)$.

\begin{tabular}{|l|l|l|}
\hline & $\begin{array}{l}\text { Theme 1: Community } \\
\text { Connectivity }\end{array}$ & $\begin{array}{l}\text { Theme 2: Children's Social } \\
\text { Capital }\end{array}$ \\
\hline Socialize with Neighbours & 0.861 & \\
\hline My New Friend & 0.779 & \\
\hline Connect with Community & 0.782 & \\
\hline Participate/Organize Events & 0.824 & 0.842 \\
\hline Mixed Age Background Play & 0.777 & 0.845 \\
\hline Safe Outdoor Play & & 0.815 \\
\hline $\begin{array}{l}\text { Children require less } \\
\text { supervision }\end{array}$ & & \\
\hline Make new friends & & \\
\hline
\end{tabular}




\section{OPENING NEIGHBOURHOOD STREETS FOR COMMUNITY-BUILDING AND CHILDREN'S OUTDOOR FREE PLAY}

Both perceptions were examined for their potential correlations with survey respondents' demographic characteristics such as their status as a parent or non-parent, age, sex and where they were born, as well as children's age and sex.

Independent sample t-tests and ANOVA tests were estimated for this purpose. In order to compare the correlates between the two components, the factor scores, which were already standardized at mean $=0$ and standard deviation $=1$ were compared. Two sets of statistical tests were conducted for each of the two themes; community connectivity and children's social capital and were compared against the mean of various demographics such as the difference in perceptions of male or female community members. The independent sample t-test was used to compare the means of demographics such as their sex; whether they had children under 16 years of age and; whether they were born in Canada and their perceptions on community connectivity and children's social capital. An independent sample t-test was used because the independent variables were measured on a categorical scale with two groups (male, female; parent, nonparent; born in Canada, not born in Canada). The results are presented as t-scores and $\mathrm{p}$ values with $95 \%$ confidence intervals. An ANOVA test was used to determine if there are statistically significant differences in how various demographic groups perceive community connectivity and children's social capital. Demographics such as community members' age and total household income in 2016 were included in the ANOVA tests because they are measured on a categorical or an interval scale with more than three categories or intervals (age: 25-34, 35-49, 50-64). The results are presented as degrees of freedom $(\mathrm{dF})$ and $\mathrm{p}$ values with $95 \%$ confidence intervals.

For the statistical tests which analyzed children's age and sex, the sample size $(n=54)$ was a subset of the neighbourhood survey sample size because approximately half of the community members reported they had children. 


\section{OPENING NEIGHBOURHOOD STREETS FOR COMMUNITY-BUILDING AND \\ CHILDREN'S OUTDOOR FREE PLAY}

\section{Chapter 4: Results \& Discussion}

\section{Benefits to children from participating in StreetPLAY programming}

The field survey was completed by 104 parents and caregivers. $89 \%$ of the respondents were between $35-49$ years of age and $58 \%$ of the respondents were female (Table 3 ). $74 \%$ of them were born in Canada and 45\% had a total household income over 160,000 in 2016.

Table 3. Summary statistics of parents and caregiver's demographics from the field survey $(\mathbf{n}=104)$.

\begin{tabular}{l|ll} 
Variable & Frequency & Percent $(\%)$ \\
\hline $\begin{array}{l}\text { Age }(\mathrm{n}=104) \\
\text { 25-34 years }\end{array}$ & 2 & 1.9 \\
35-49 years & 93 & 89.4 \\
50-64 years & 9 & 8.7 \\
Sex (n=104) & 60 & \\
Female & 43 & 57.7 \\
Male & 1 & 41.3 \\
Other & & 1.0 \\
Born in Canada (n=104) & 27 & \\
No & 77 & 26.0 \\
Yes & & 74.0 \\
Total household income in 2016 (n=73) & 1 & \\
20,000 to 39,000 & 9 & 1.4 \\
40,000 to 79,000 & 14 & 12.3 \\
80,000 to 119,000 & 16 & 19.2 \\
120,000 to 159,000 & 33 & 21.9 \\
160,000 or more & & 45.2 \\
\hline
\end{tabular}

More girls participated in StreetPLAY than boys (55.41\% vs 44.24\%). The largest age group of children to attend StreetPLAY were 4-7 years of age (40.26\%), followed by children 811 years of age.

StreetPLAY was frequently attended by children and youth. $66.2 \%$ of participating children attended StreetPLAY more than once since the program started and $28.6 \%$ of children attended all of the events on their street (Table 4). The results suggest that when offered the opportunity to play on their street close to their home, children took advantage of the opportunity more than once, if not at every opportunity they were given.

The programming brought children outside onto the street to play for longer than they generally would have on a typical day without StreetPLAY. When not at StreetPLAY, 21.3\% of children played outdoors for more than 2 hours, whereas at StreetPLAY 27.6\% of children 


\section{OPENING NEIGHBOURHOOD STREETS FOR COMMUNITY-BUILDING AND CHILDREN'S OUTDOOR FREE PLAY}

played outside for more than 2 hours. When participating at a StreetPLAY event, children and youth would most commonly spend more than 1 hour at StreetPLAY (61.5\%), while about one in every four children (24.3\%) would spend between 30 and 60 minutes at these events. With regard to the potential alternative activities that a child would engage in, a large proportion of participating parents reported that their children would either play indoors $(61.1 \%)$ or use the internet (34\%) if they were not at a StreetPLAY event (Table 4). Based on these results, it can be argued that StreetPLAY events created opportunities for regular physical activity and social play, both of which are critically important for their health and wellbeing (Faulkner et al., 2015; ParticipACTION, 2015). These opportunities to socially interact with neighbours and make friends with other children on the street helps children expand their social network in addition to developing their social skills, which are beneficial to their overall healthy development (Valentine \& McKendrick, 1997; Cheng \& Johnson, 2010; Gleave \& Cole-Hamilton, 2012; Faulkner et al, 2015). Although the primary focus of this study is on examining the social benefits of the play intervention, the increased play time allows for higher physical activity accumulation for children which carries significant health benefits as well, such as reducing risks of obesity, diabetes and hypertension (Guillaume, 1997; Frederick et al, 2014).

The survey findings indicate that children participated in a diversity of play activities, from cycling and skateboarding to water play, from hula hooping to colouring (Table 5). During the field observations, we also observed a range of play activities that were novel and created by the children, activities that do not necessarily have a name. Children created new games using various toys, and built things using miscellaneous household items. Children were observed walking the cat on a leash, washing the bike, crawling, learning to walk, having a picnic on a blanket that was laid out and playing with the water hose and wagon.

This practice of self-directed play is well-documented in literature as helping them develop social skills (Ness \& Farenga, 2007). Zieff et al (2016) and Murray \& Devecchi (2016) indicate that play should be voluntary and self-directed play where children have opportunities to engage in appropriate risk taking. Self-directed play allows children to learn to work in teams and share, to negotiate and solve problems, to discover new interests and pursue new passions (Ginsburg, 2007). In adult-directed play where rules are in place, there may be limited opportunities to develop their creativity, leadership and teamwork skills (Ginsburg, 2007). These 


\section{OPENING NEIGHBOURHOOD STREETS FOR COMMUNITY-BUILDING AND CHILDREN'S OUTDOOR FREE PLAY}

studies highlight the importance of children's independent mobility, and the ability to access and play in local spaces without complete adult supervision.

StreetPLAY also provided an opportunity for parents to socialize with others in the community. $70.2 \%$ talked to people they knew, and 52.9\% talked to people they did not know. This indicates StreetPLAY provided the opportunity for parents to meet new people and build social capital. $24 \%$ of parents helped the organizers with StreetPLAY programming and set up. StreetPLAY created new opportunities for volunteering and helping out, which may help foster a sense of community and belonging among parents.

Table 4. Summary statistics of children's demographics and participation at StreetPLAY from the field survey $(n=158)$.

\begin{tabular}{l|ll} 
Variable & Frequency & Percent (\%) \\
\hline Age of children $(\mathrm{n}=154)$ & 24 & 15.58 \\
0-3 years old & 62 & 40.26 \\
4-7 years old & 53 & 34.41 \\
8-11 years old & 15 & 9.74 \\
12 years and up & & \\
Sex of children $(\mathrm{n}=157)$ & 87 & 55.41 \\
Female & 69 & 44.24 \\
Male & 1 & 0.01 \\
Other & & \\
Time children spent at StreetPLAY (n=156) & 22 & 14.1 \\
Less than 30 minutes & 38 & 24.4 \\
30-60 minutes & 53 & 33.9 \\
1-2 hours & 43 & 27.6 \\
More than 2 hours & & \\
Time children spend playing outdoors generally (n=155) & 18 & 11.6 \\
Less than 30 mins & 44 & 28.4 \\
30 mins to 1 hour & 60 & 38.7 \\
1 to 2 hours & 33 & 21.3 \\
More than 2 hours & & \\
Frequency of visit to StreetPLAY (n=154) & 8 & 5.2 \\
This was my first time & 102 & 66.2 \\
More than once since the program started & 44 & 28.6 \\
I have come to all of the events on my street & & \\
\hline
\end{tabular}

Table 5. Summary statistics of activities children participated in at StreetPLAY from the field survey. 


\section{OPENING NEIGHBOURHOOD STREETS FOR COMMUNITY-BUILDING AND CHILDREN'S OUTDOOR FREE PLAY}

Running around ( $\mathrm{n}=158)$

128

81.0

Cycling/skateboarding/scootering $(\mathrm{n}=158)$

111

70.3

Ball games $(\mathrm{n}=158)$

100

63.3

Drawing/ colouring on sidewalks $(\mathrm{n}=158)$

71

Blowing bubbles $(\mathrm{n}=58)$

Skipping $(\mathrm{n}=157)$

Racing games $(\mathrm{n}=158)$

51

44.9

Hula hoops $(\mathrm{n}=158)$

48

32.3

Hopscotch $(\mathrm{n}=157)$

I don't know $(\mathrm{n}=158)$

Children's Activities When Not At StreetPLAY

Indoor play (such as lego, drawing, toy) $(\mathrm{n}=157)$

\section{4}

96

89

Outdoor play (such as in back/front yard, park) $(\mathrm{n}=157)$

$\mathrm{TV} /$ internet/video games $(\mathrm{n}=156)$

Other programmed activities (such as arts, music) $(\mathrm{n}=157)$

Homework $(\mathrm{n}=157)$

Stay at a daycare/ afterschool program $(\mathrm{n}=157)$

Organized sport (such as soccer, swimming) $(n=157)$

Parents activity during StreetPLAY

Talked to people I knew $(\mathrm{n}=104)$

Watched my children $(\mathrm{n}=104)$

Just relaxed while children played $(\mathrm{n}=104)$

Talked to people I did not know $(\mathrm{n}=104)$

Played with children $(n=104)$

Helped the organizers $(n=104)$

Other
2.5

61.1

56.7

34.0

11.5

10.2

6.4

5.7

70.2

69.2

65.4

52.9

35.2

24.0

15.2

\section{Social benefits to the Community from Street Play}

We collected 105 neighbourhood surveys from respondents in the community. $47 \%$ of the respondents did not have children under 16 years of age (Table 6). $52 \%$ of the respondents were between $35-49$ years of age, and $60 \%$ of the respondents were female. Over one third (37.7\%) of the respondents had a total household income over $\$ 160,000$ in 2016.

Table 6. Summary statistics of demographics from the neighbourhood survey $(n=105)$.

\begin{tabular}{l|lc} 
Variable & Frequency & Perc \\
\hline $\begin{array}{l}\text { Community members with children under } 16 \\
\text { years of age }(\mathrm{n}=105)\end{array}$ & & \\
$\quad$ No children & 49 & 46.7 \\
$\quad$ Children & 56 & 53.3 \\
Age $(\mathrm{n}=105)$ & & \\
Under 18 years & 1 & 1.0 \\
18-24 years & 4 & 3.8
\end{tabular}




\section{OPENING NEIGHBOURHOOD STREETS FOR COMMUNITY-BUILDING AND CHILDREN'S OUTDOOR FREE PLAY}

\begin{tabular}{l|ll}
$25-34$ years & 11 & 10.5 \\
35-49 years & 55 & 52.4 \\
50-64 years & 25 & 23.7 \\
65 years or over & 9 & 8.6 \\
Sex $(\mathrm{n}=103)$ & & \\
Female & 62 & 60.1 \\
Male & 40 & 38.8 \\
Other & 1 & 0.9 \\
Total household income in $2016(\mathrm{n}=61)$ & & \\
Less than 20,000 & 3 & 1.6 \\
20,000 to 39,000 & 7 & 4.9 \\
40,000 to 79,000 & 17 & 11.5 \\
80,000 to 119,000 & 10 & 27.9 \\
120,000 to 159,000 & 23 & 16.4 \\
160,000 or more &
\end{tabular}

Almost all of the community members (91.4\%) felt that the StreetPLAY events offered a safe play environment for children, where children can play without constant adult supervision $(67.6 \%)$ and make new friends (83.8\%) (Table 6). There appears to be not much disagreement about the benefits of these events to children in the community.

Beyond benefits to children, the StreetPLAY pilot project improved the sense of community, citizenship and belonging among community members (Table 7). The majority of community members $(75.3 \%)$ also felt more connected to their community as a result of the StreetPLAY program, and $84.8 \%$ agreed it provides an opportunity for different age and backgrounds to interact. Community members agreed more strongly that StreetPLAY was an opportunity for children to make friends $(83.8 \%)$ than they agreed it was an opportunity for themselves to make new friends $(67 \%)$. Community members also reported that they were more likely to participate and/or organize social events in the neighbourhood. This finding was consistent across both parent and non-parent community members. More broadly, these descriptive findings suggest that community members view the social benefits of StreetPLAY to children as more apparent than the social benefit to all community members.

Table 7. Summary statistics of community member's perceptions from the neighbourhood survey $(n=105)$.

Variable

StreetPLAY has offered a safe outdoor play environment for children $(n=105)$

Agree

Frequency Percent (\%)

$96 \quad 91.4$ 


\section{OPENING NEIGHBOURHOOD STREETS FOR COMMUNITY-BUILDING AND \\ CHILDREN'S OUTDOOR FREE PLAY}

Neutral

Disagree

StreetPLAY requires less adult supervision when children play outside $(\mathrm{n}=105)$

Agree

Neutral

Disagree

StreetPLAY provides an opportunity for a child to make new friends $(n=105)$

Agree

Neutral

Disagree

StreetPLAY provides an opportunity for me to socialize with neighbours $(\mathrm{n}=105)$

Agree

Neutral

Disagree

StreetPLAY provides an opportunity for people of mixed age and backgrounds to interact $(n=105)$

Agree

Neutral

Disagree

StreetPLAY offers an opportunity for me to make new friends $(n=103)$

Agree

Neutral

Disagree

I am more likely to participate/organize social/community events in this neighbourhood $(n=105)$

Agree

Neutral

Disagree

Makes me feel more connected to the community $(n=105)$

Agree

Neutral

Disagree

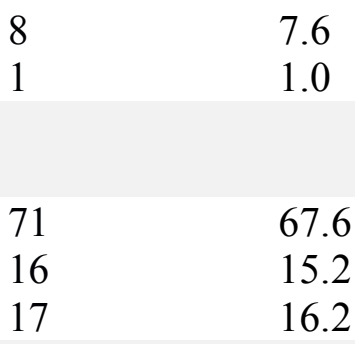

83.8

12.4

3.8

76.2

13.3

4.8

89

84.8

$10 \quad 9.5$

$6 \quad 8.6$

$69 \quad 67.0$

$23 \quad 22.3$

$\begin{array}{ll}10 & 9.7\end{array}$

$63 \quad 60$

$33 \quad 31.4$

98.6

$79 \quad 75.3$

$15 \quad 14.3$

$11 \quad 10.5$

Independent sample t-tests and ANOVA tests were used to analyze on the potential differences in community members' perception of (1) community connectivity and (2) children's social capital, across various socio-demographic groups. Results from this analysis are summarized in Table 8 . Whether a community member had children or not (under 16 years of age) was statistically important in explaining perceptions of community connectivity. More 


\section{OPENING NEIGHBOURHOOD STREETS FOR COMMUNITY-BUILDING AND CHILDREN'S OUTDOOR FREE PLAY}

specifically, community members who had children had, on average, more positive perceptions towards the community's connectivity following StreetPLAY.

Age of community members was also statistically significant in explaining perceptions of community connectivity. Community members in the 25-34 age group and all older age groups had more positive perceptions towards the community's connectivity, compared to age groups under 25. Other socio-demographic characteristics of either the parents or their children did not influence perceptions around community connectivity.

Table 8. Summary of results from independent sample t-test and ANOVA tests to analyze potential impact of demographics on community member's perception on community connectivity

\begin{tabular}{|c|c|c|c|c|c|}
\hline $\begin{array}{l}\text { Socio-demographic } \\
\text { characteristics }\end{array}$ & $\mathbf{n}$ & Mean & $\begin{array}{l}\text { Std. } \\
\text { Dev. }\end{array}$ & Test-score & P-value \\
\hline Parent & 105 & & & $\begin{array}{l}\mathrm{t}=4.884 \\
(\mathrm{dF}=81.95)\end{array}$ & $<0.001$ \\
\hline $\begin{array}{l}\text { Parent of children } \\
\text { Not parent }\end{array}$ & $\begin{array}{l}56 \\
49\end{array}$ & $\begin{array}{l}0.412 \\
-0.471\end{array}$ & $\begin{array}{l}0.718 \\
1.073\end{array}$ & & \\
\hline Gender of parents & 102 & & & $\begin{array}{l}\mathrm{t}=-0.869 \\
(\mathrm{dF}=94.63)\end{array}$ & 0.387 \\
\hline Male & 40 & 0.123 & 0.859 & & \\
\hline Female & 62 & -0.043 & 1.055 & & \\
\hline Age of parents & 105 & & & $\begin{array}{l}F=3.894 \\
(d F=5)\end{array}$ & 0.003 \\
\hline Under 18 years & 1 & -0.642 & & & \\
\hline $18-24$ years & 4 & -0.727 & 0.875 & & \\
\hline $25-34$ years & 11 & 0.902 & 0.266 & & \\
\hline $35-49$ years & 55 & 0.344 & 0.101 & & \\
\hline 50-64 years & 25 & 0.464 & 0.248 & & \\
\hline 65 or over & 9 & 0.534 & 0.201 & & \\
\hline Household income & 61 & & & $\begin{array}{l}\mathrm{F}=3.035 \\
(\mathrm{dF}=7)\end{array}$ & 0.006 \\
\hline Less than $\$ 20,000$ & 1 & -0.620 & & & \\
\hline$\$ 20,000$ to $\$ 39,000$ & 3 & -0.790 & 2.195 & & \\
\hline$\$ 40,000$ to $\$ 79,000$ & 7 & -0.257 & 1.060 & & \\
\hline$\$ 80,000$ to $\$ 119,000$ & 17 & 0.430 & 0.560 & & \\
\hline$\$ 120,000$ to $\$ 159,000$ & 10 & 0.243 & 0.728 & & \\
\hline$\$ 160,000$ or more & 23 & 0.452 & 0.694 & & \\
\hline Born in Canada & 104 & & & $\begin{array}{l}\mathrm{t}=0.683 \\
(\mathrm{dF}=33.706)\end{array}$ & 0.499 \\
\hline Yes & 82 & -0.024 & 1.005 & & \\
\hline No & 22 & 0.139 & 0.985 & & \\
\hline Gender of child & 54 & & & $\begin{array}{l}t=-1.262 \\
(d F=39.545)\end{array}$ & 0.214 \\
\hline
\end{tabular}




\section{OPENING NEIGHBOURHOOD STREETS FOR COMMUNITY-BUILDING AND CHILDREN'S OUTDOOR FREE PLAY}

\begin{tabular}{l|lllll} 
Male & 23 & 0.259 & 0.828 & & \\
Female & 31 & 0.520 & 0.629 & & \\
Age of child & 52 & & & $\begin{array}{l}\mathrm{F}=0.893 \\
(\mathrm{dF}=15)\end{array}$ & 0.578 \\
& & & & \\
$0-3$ years old & 9 & 0.704 & 0.492 & \\
4-7 years old & 20 & 0.342 & 0.763 & \\
8-11 years old & 14 & 0.547 & 0.811 & \\
$12+$ years old & 9 & 0.984 & 0.489 & \\
\hline
\end{tabular}

Table 9 summarizes independent sample t-tests and ANOVA tests on perceptions of children's social capital. Similar to results on community connectivity, results from these tests also indicate that community members who had children had higher perceptions towards children's social capital following StreetPLAY. The average score for parents was 0.252 , compared to non-parents who had an average score of -0.288 thus parents had more positive perception towards on children's social capital than non-parents.

Perceptions of a child's social capital did not vary based on community members' age, unlike perceptions on community connectivity.

Table 9. Summary of results from independent sample t-test and ANOVA tests to analyze potential impact of demographics on community member's perception on children's social capital

\begin{tabular}{|c|c|c|c|c|c|}
\hline $\begin{array}{l}\text { Socio-demographic } \\
\text { characteristics }\end{array}$ & $\mathbf{n}$ & Mean & $\begin{array}{l}\text { Std. } \\
\text { Dev. }\end{array}$ & Test-score & P-value \\
\hline Parent & 105 & & & $\begin{array}{l}\mathrm{T}=2.795 \\
(\mathrm{df}=84.721)\end{array}$ & 0.005 \\
\hline $\begin{array}{l}\text { Parent of children } \\
\text { Not parent }\end{array}$ & $\begin{array}{l}56 \\
49\end{array}$ & $\begin{array}{l}0.252 \\
-0.288\end{array}$ & $\begin{array}{l}0.796 \\
1.132\end{array}$ & & \\
\hline Gender of parents & 102 & & & $\begin{array}{l}\mathrm{T}=-1.336 \\
(\mathrm{df}=97.233)\end{array}$ & 0.211 \\
\hline $\begin{array}{l}\text { Male } \\
\text { Female }\end{array}$ & $\begin{array}{l}40 \\
62\end{array}$ & $\begin{array}{l}0.180 \\
-0.068\end{array}$ & $\begin{array}{l}0.807 \\
1.063\end{array}$ & & \\
\hline Age of parents & 105 & & & $\begin{array}{l}F=2.823 \\
(\mathrm{df}=5)\end{array}$ & 0.02 \\
\hline $\begin{array}{l}\text { Under } 18 \text { years } \\
18-24 \text { years } \\
25-34 \text { years } \\
35-49 \text { years } \\
50-64 \text { years } \\
65 \text { or over }\end{array}$ & $\begin{array}{l}1 \\
4 \\
11 \\
55 \\
25 \\
9\end{array}$ & $\begin{array}{l}1.220 \\
-0.992 \\
0.533 \\
0.129 \\
-0.368 \\
-0.114\end{array}$ & $\begin{array}{l}1.517 \\
0.793 \\
0.836 \\
1.209 \\
0.791\end{array}$ & & \\
\hline Household income & 61 & & & $\begin{array}{l}F=2.189 \\
(d f=7)\end{array}$ & 0.042 \\
\hline Less than $\$ 20,000$ & 1 & 0.820 & & & \\
\hline
\end{tabular}




\section{OPENING NEIGHBOURHOOD STREETS FOR COMMUNITY-BUILDING AND CHILDREN'S OUTDOOR FREE PLAY}

\begin{tabular}{|c|c|c|c|c|c|}
\hline$\$ 20,000$ to $\$ 39,000$ & 3 & -0.361 & 1.985 & & \\
\hline$\$ 40,000$ to $\$ 79,000$ & 7 & -0.111 & 1.077 & & \\
\hline$\$ 80,000$ to $\$ 119,000$ & 17 & 0.373 & 0.583 & & \\
\hline$\$ 120,000$ to $\$ 159,000$ & 10 & 0.053 & 0.876 & & \\
\hline$\$ 160,000$ or more & 23 & 0.349 & 0.861 & & \\
\hline Born in Canada & & & 0 & $\begin{array}{l}\mathrm{T}=0.763 \\
(\mathrm{df}=33.137)\end{array}$ & 0.451 \\
\hline Yes & 82 & -0.024 & 0.995 & & \\
\hline No & 22 & 0.159 & 0.996 & & \\
\hline Gender of child & & & & $\begin{array}{l}\mathrm{T}=-0.790 \\
(\mathrm{df}=43.448)\end{array}$ & 0.434 \\
\hline Male & 23 & 0.144 & 0.869 & & \\
\hline Female & 31 & 0.323 & 0.753 & & \\
\hline Age of child & & & & $\begin{array}{l}F=0.574 \\
(d f=15)\end{array}$ & 0.875 \\
\hline $0-3$ years old & 9 & 0.246 & & & \\
\hline 4-7 years old & 20 & 0.276 & & & \\
\hline $8-11$ years old & 14 & 0.232 & & & \\
\hline $12+$ years old & 9 & 0.197 & & & \\
\hline
\end{tabular}




\section{OPENING NEIGHBOURHOOD STREETS FOR COMMUNITY-BUILDING AND CHILDREN'S OUTDOOR FREE PLAY}

\section{Chapter 6: Implications \& Conclusion}

The purpose of this study was to explore the neighbourhood-level benefits of the programming interventions focusing on children's use of local streets for outdoor play. In particular, a pilot program in Toronto, Canada, called StreetPLAY, was evaluated. The community generally responded positively to the programming and reported high perceptions of how the programming benefitted them socially. In our study, community members agreed StreetPLAY offered a safe outdoor environment for children (91.4\%) and agreed children required less adult supervision during StreetPLAY (67.6\%).

Children's access to neighbourhood and the opportunity to unsupervised exploration and free play has been overlooked in recent decades by urban planners (Wood, 2017). Planning local neighbourhood streets and public spaces to accommodate children and people of all ages is crucial to welcoming citizens back into these spaces and for children to have a sense of belonging in their neighbourhood. Since parent's play a critical role in the duration and kind of

outdoor play children partake in, it is important to plan these spaces to the needs of families as a whole. In doing so, both children and adult members of the community would have the opportunity to build their social skills. Street play interventions provide this opportunity to engage with neighbours and socially benefit from the interactions. Tactical urbanism interventions like StreetPLAY demonstrate the social benefit to community members and with wider implementation in municipal initiatives their positive social impacts can become more pronounced across more neighbourhoods (Lydon \& Garcia, 2015). In the short term, these interventions are citizen-led responses to reclaiming streets for their own social capital development, where municipal policy and initiatives fall behind.

Several North American and European studies have argued that children prefer natural, informal play spaces and streets near their homes than playgrounds (Valentine and McKendrick, 1998; Aitken, 2000; Jones and Barker, 2000; Castonguay and Jutras, 2009). Policy changes and the trends in recent decades do not fully consider children's access to urban spaces beyond planned facilities such as schools and playgrounds (Read, 2011; Cunningham and Jones, 1999; Hart, 2002; Freeman, 2006; Wood, 2017). The recent culture and policies which favour vehicles as the primary users of the street act as barriers in shifting the current practice to allow people to use neighbourhood street for other uses than transportation. Small, inexpensive and locally programmed tactics like the StreetPLAY intervention are a way to spur change in behaviour at 


\section{OPENING NEIGHBOURHOOD STREETS FOR COMMUNITY-BUILDING AND CHILDREN'S OUTDOOR FREE PLAY}

the neighbourhood level for both types of users- the automobile users and the residents participating in play interventions. The effort to shift the trend at the miniscule, local level has the potential to have greater social impacts with increased activation on many local neighbourhood streets across the city.

$83.8 \%$ of community members agreed that StreetPLAY provided an opportunity for them to socialize with neighbours and $75.3 \%$ agreed the programming made them feel more connected to the community. However, our analysis indicated that those who had children had a more positive perception of the benefits of StreetPLAY overall compared to those who did not have children, with regard to community connectivity and children's social capital. Community members felt StreetPLAY provided an opportunity for children to make new friends $(84.8 \%)$, more than they felt it provided an opportunity for themselves to make friends (67\%). These findings are consistent with a study of a similar play intervention in Ghent, Belgium where parents agreed children socially interacted more with others than parents did at the events (D’Haese et al., 2015). These results indicate community members may not perceive these events as a socializing opportunity for themselves as much as they do for the children of the community. Strategies and programming activities targeted at engaging adults without children in the community in play street interventions will be important to understand the value of street play interventions as a social capital and community-building opportunity for all. Furthermore, the observed perceptions of community connectivity may relate to adults' childhood experiences and habits, where older adults might have played outside independently when they were children, and as a result, are more receptive of such interventions.

Low income households were underrepresented in this study, which may be explained by the geographic location of the neighbourhood in which this play intervention took place; the average household income in this neighbourhood was higher than the Toronto-wide median. Therefore, the performance and social benefits of such play interventions among lower socioeconomic status families remains to be explored. Street play interventions outside their door step may be an inexpensive option for community social interactions, particularly for low income neighbourhoods which may suffer from poor local infrastructure and low quality of recreational facilities and parks, transportation and neighbourhood environment (Reitsma-Street, 2000). The capacity of producing such tactical play interventions may vary in different socio-economic status neighbourhoods however. Lower socio-economic status neighbourhoods may not be as 


\section{OPENING NEIGHBOURHOOD STREETS FOR COMMUNITY-BUILDING AND CHILDREN'S OUTDOOR FREE PLAY}

directly involved in advocating or implementing community-building interventions, as research suggests they may undermine civic engagement and have poorer perceptions of the neighbourhood (Reitsma-Street, 2000), which is also a challenge to overcome if play streets are extended to these neighbourhoods.

It is important for urban planners to consider the safety on streets in fostering a play environment that is conducive to children and families. One study found that parents perceived connecting or through-streets to be unsafe for children, which may limit their opportunities to play outside if they live on such a street (Veitch et al., 2006). Introducing play interventions such as StreetPLAY, which temporarily close off neighbourhood streets to traffic, can be a way to reclaim the street, even if for a few hours, for all users of the street to enjoy equitably. It aids in creating the 'third place' (Oldenburg, 1989, 2001) where every community member feels welcome to and regularly uses. The predominance of vehicles and safety issues related to them require more strategic planning to secure municipal support to implement play streets more widely.

In the context of Toronto's pilot program, the primary actors implementing the StreetPLAY intervention were community leaders and local city staff. Urban planners must understand their key role in planning child-friendly streets and public spaces and take on greater responsibility within this planning realm. A lack of policy in place around children's outdoor free play and the use of streets by multiple users have contributed to urban planners' lack of attention to children in practice. For example, a study on Scottish play work planning and policy found the lack of statutory support for informal play spaces further discourages planners to incorporate it into practice (Wood, 2017). The Scottish study suggests that play has been framed primarily as social policy which in many times is considered voluntary in comparison to economic planning policy (Wood, 2017). In the context of Toronto, the lifting of the play ban in Toronto served as a basis for the StreetPLAY pilot program to occur, thus indicating the importance of such policy changes in affecting opportunities for children and communities to participate in outdoor free play on their local neighbourhood streets. Urban planning must consider the low cost, low maintenance, community-driven play interventions as a novel opportunity to re-introduce play onto the streets once again.

This study also indicates the importance of implementing physical changes, such as a street closure, as just as important, if not more, to creating a welcoming environment for outdoor 


\section{OPENING NEIGHBOURHOOD STREETS FOR COMMUNITY-BUILDING AND CHILDREN'S OUTDOOR FREE PLAY}

free play. A previous study on a similar play intervention found that programs which encouraged children's participation without environmental changes to do so resulted in low participation rates (Ngo et al, 2014). Shifting a greater attention to opening up streets for all users of the community will require a multisector approach (Villanueva, 2013), with planners at the helm understanding their responsibility (Wood, 2017) to ensure children can safely access local neighbourhood streets and public spaces for their free play and exploration. Temporary interventions based on the tactical urbanism principles can be an effective way of experimenting different alternative solutions, and build public and political support toward larger scale shifts in policy and practice.

The findings from this study suggest community members generally had a positive perception of their community connectivity, citizenship and children's social capital, safety and supervisions. The results indicate parents out of all of the community members appeared to have socially benefitted the most from the play intervention. Specific programming strategies should be explored to foster a more inclusive and welcoming play street environment for all community members to attend, particularly for adults without children, and senior citizens. In the Toronto case study that was examined, the community was receptive to this pilot programming, which demonstrates the potential for urban planners to replicate such play interventions in other similar urban neighbourhoods. As the first-of-its-kind study of play intervention of its type in Toronto, my study provides valuable insights into the benefits of such interventions, and on what needs to be done to implement similar play interventions in the city of Toronto. Re-introducing streets for all users of the space has its benefits, but it requires policy support, continued community support and greater attention and resources from the field of urban planning. 


\section{OPENING NEIGHBOURHOOD STREETS FOR COMMUNITY-BUILDING AND CHILDREN'S OUTDOOR FREE PLAY}

\section{References}

Aitken, S. (2000). 'Play, rights and borders: gender-bound parents and the social construction of childhood', in G. Valentine and S. L. Holloway (eds), Children's Geographies: Playing, Living, Learning, London and New York, Routledge, 119-38.

Burdette H, Whitaker R., (2005). A national study of neighborhood safety, outdoor play, television viewing, and obesity in preschool children. Pediatrics.116(3):657-62

Bringolf-Isler, B., Grize, L., Mäder, U., Ruch, N., Sennhauser, F., Braun-Fahrländer, C., \& SCARPOL Team. (2010). Built environment, parents' perception, and children's vigorous outdoor play. Preventive Medicine, 50, 251-256.

Canadian Index of Wellbeing. (2016). How are Canadians Really Doing? The 2016 CIW National Report. Waterloo, ON: Canadian Index of Wellbeing and University of Waterloo.

Canadian Society for Exercise Physiology. (2011). Canadian physical activity guidelines. Retrieved from http://www.csep.ca/guidelines

Cantello, I., Mitra, R., Buliung, R. (2016). Children's Activity Lifestyles, Physical Activity Participation and Social-Ecological Correlates in Toronto, Canada. Journal of Transport \& Health, 3(2), S28.

Carver, A., Timperio, A., \& Crawford, D. (2008). Playing it safe: The influence of neighbourhood safety on children's physical activity-A review. Health and Place, 14(2), 217-227. 10.1016/j.healthplace.2007.06.004

Castonguay, G. and Jutras, S. (2009). 'Children's appreciation of outdoor places in a poor neighborhood', Journal of Environmental Psychology, 29, 101-09.

Cheng, M., \& Johnson, J. (2010). Research on children's play: Analysis of developmental and early education journals from 2005 to 2007. Early Childhood Education Journal, 37, 249259.

City of Kingston (2017). By-Law to Regulate the Use of City Streets. Corporation of the City of Kingston, Ontario, By-Law Number 2004-190. https://www.cityofkingston.ca/documents/10180/16904/Streets+Bylaw

City of Toronto (2011). Playing of Ball Sports on Residential Streets In Toronto. City of Toronto Staff Report to Public Works and Infrastructure Committee. https://www.toronto.ca/legdocs/mmis/2011/pw/bgrd/background le-37328.pdf

City of Toronto (2016). By-law no. 775-2016. Public Works and Infrastructure Committee Item PW14.11. City of Toronto.

City of Toronto Social Policy Analysis \& Research (2011). Annex Demographics. City of Toronto.

Coombs, G., (2012). Park(ing) Day. Contexts. 11(3) 64-65. https://doi.org/10.1177/1536504212456186

Cooper, A., Page, A., Wheeler, B., Hillsdon, M., Griew, P., \& Jago, R. (2010). Patterns of GPS measured time outdoors after school and objective physical activity in English children: The PEACH Project. International Journal of Behavioral Nutrition and Physical Activity, $7(31)$.

Cortinez-O’Ryan, A., Albagli, A., Sadarangani, K., \& Aguilar-Farias, N. (2017). Reclaiming streets for outdoor play: A process and impact evaluation of "Juega en tu barrio" (play in your neighborhood), an intervention to increase physical activity and opportunities for play. PLoS One, 12(7). http://dx.doi.org.ezproxy.lib.ryerson.ca/10.1371/journal.pone.0180172 


\section{OPENING NEIGHBOURHOOD STREETS FOR COMMUNITY-BUILDING AND CHILDREN'S OUTDOOR FREE PLAY}

Cunningham, C. and Jones, M. (1999). 'The playground: a confession of failure?', Built Environment, 25, 11-17.

D’Haese S., Van Dyck, D., De Bourdeaudhujj, I., Deforche, B., \& Cardon, G. (2015). Organizing "Play Streets" During School Vacations Can Increase Physical Activity And Decrease Sedentary Time in Children. International Journal of Behavioural Nutrition and Physical Activity. 12(1):14.

Ding, D., Sallis, J, Kerr, J., Lee, S., \& Rosenberg, D. (2011). Neighbourhood Environment and Physical Activity Among Youth: A Review. American Journal of Preventive Medicine 4(1): 442-455.

Earth Day Canada (2018). Toronto StreetPLAY Pilot Project Summary Report. https://earthday.ca/wp-content/uploads/2018/02/StreetPLAY-Report-Final.pdf

Faulkner, G., Mitra., R., Buliung, R., Fusco, C., \& Stone, M. (2015) Children's outdoor play time, physical activity and parental perceptions of neighbourhood environment. International Journal of Play, 4(1), 84-97.

Ferguson, A., Page, A. (2015). Austerity as Opportunity Supporting Healthy Street Play on a Budget: A Winner from Every Perspective. International Journal of Play, 4(3), 266-269.

Floyd M., Bocarro J., Smith W. (2011). Park-based physical activity among children and adolescents. Am J Prev Med.41(3):258-65

Fotel, T. (2009). Marginalized or Empowered? Street Reclaiming Strategies and the Situated Politics of Children's Mobilities. Geography Compass 3/3: 1267-1280, 10.1111/j.17498198. 2009.00235.x

Freeman, C. (2006). 'Colliding worlds: planning with children and young people for better cities', in B. Gleeson and N. G. Sipe (eds), 69-85.

Fredrick C., Snellman K., Putnam R. (2014). Increasing socioeconomic disparities in adolescent obesity. Proc Natl Acad Sci USA, 2014;111(4):1338-1342

Gill, T., (2014) The Play Return. London: Children's Play Policy Forum.

Ginsburg, K. R. (2007). The Importance of Play in Promoting Healthy Child Development and Maintaining Strong Parent-Child Bonds. Pediatrics, 119(1), 182+.

Gleave, J., \& Cole-Hamilton, I. (2012). A literature review on the effects of a lack of play on children's lives. London: Play England.

Guillaume, M., Lapidus, L., Jorntorp, P., Lambert, A. (1997). Physical activity, obesity, and cardiovascular risk factors in children. The Belgian Luxembourg Child Study 2. Obesity Research 5, 549-556.

Hart, R. (2002). Containing Children: Some Lesson on Planning for Play from New York City. Environment \& Urbanization, 14(2), 135-148.

Humbert, M., Chad, K., Spink, K., et al., (2006). Factors that influence physical activity participation among high- and low-SES youth. Quality Health Research 16 (4), 467-483.

Jarvis, P., Newman, S., \& Swiniarski, I. (2014). On "becoming social": The importance of collaborative free play in childhood. International Journal of Play, 3(1): 53-68.

Jones, O. and Barker, J. (2000). 'Melting geography: purity, disorder, childhood and space', in G. Valentine and S. L. Holloway (eds), Children's Geographies: Playing, Living, Learning, London and New York, Routledge, 28-47.

Kaboom (2008). New York City: Streets Renaissance Campaign, Streets as Space to Play. kaboom.org/bestpractices 


\section{OPENING NEIGHBOURHOOD STREETS FOR COMMUNITY-BUILDING AND CHILDREN'S OUTDOOR FREE PLAY}

Karsten, L., (2005). It all used to be better? Different generations on continuity and change in urban children's daily use of space. Children's Geographies 3 (3), 275-290

Kellock, P. (2015). The Case for Play. Playground Ideas. http://www.yorkshireplay.co.uk/wpcontent/up loads/2015/10/The-case-for-play-V5.pdf

Klesges, R., Eck, L., Hanson, C., Haddock, C., Klesges, L. (1990). Effects of obesity, social interactions, and physical environment on physical activity in preschoolers. Health Psychology 9 (4), 435-449.

Louv, R. (2005). Last Child in the Woods. New York, NY: Workman.

Lydon, M., \& Garcia, A. (2015). Tactical Urbanism : Short-term Action for Long-term Change. Washington, DC: Island Press.

Metro news (2017). Home in Toronto's Seaton Village Neighbourhood Appreciates 62\% in Two Years. Torstar News Service.

Michalos, A., Smale, B., Labonte, R., Muharjarine, N., Scott, K., Moore, K., Swystun, L., Holden, B., Bernardin, H., Dunning, B., Graham, P., Gadermann, A., Zumbo, B., Morgan, A., Brooker, A., \& Hyman, I. (2011). The Canadian Index of Wellbeing Technical Report 1.0. Waterloo, ON: Canadian Index of Wellbeing and University of Waterloo.

Moyles, J. (2015). The excellence of play, 4e. Maidenhead: Open University Press/ McGraw Education.

Murray, J. \& Devecchi, C. (2016). The Hantown Street Play Project, 5 (2): 196-211. National Playing Fields Association, Children's Play Council and Playlink. (2000). Best play. What play provision should do for children. London: Author.

Ness, D., Farenga, S. (2007). Knowledge Under Construction: The Important of Play in Developing Children's Spatial and Geometric Thinking. U.S: Rowman \& Little eld Publishers, Inc.

Ngo C., Pan C., Finkelstein E., Lee C., Wong I., Ong J, et al. (2014). A cluster randomised controlled trial evaluating an incentive-based outdoor physical activity programme to increase outdoor time and prevent myopia in children. Ophthalmic Physiol Opt. 34: 362368

Offer, S., \& Schneider, B. (2007). Children's role in generating social capital. Social Forces, $85(3), 1125-1142$.

Oldenburg, R., (1989). The Great Good Place: Cafes, Coffee Shops, Bookstores, Bars, Hair Salons and Other Hangouts at the Heart of a Community. Marlowe \& Co, New York.

Oldenburg, R. (Ed.), (2001). Celebrating the Third Place: Inspiring Stories about the "Great Good Places" at the Heart of our Communities. Marlowe \& Company, New York.

Page, A., Cooper, A., Griew, P., Davis, L., \& Hillsdon, M. (2009). Independent mobility in relation to weekday and weekend physical activity in children aged 10-11 years: The PEACH project. The International Journal of Behavioral Nutrition and Physical Activity.

ParticipACTION (2015). Position Statement on Active Outdoor Play. International Journal of Environmental Research and Public Health, 12(6).

Page, A., Cooper, A., Griew, P., \& Jago, R. (2010). Independent mobility, perceptions of the built environment and children's participation in play, active travel and structured exercise and sport: The PEACH project. International Journal of Behavioral Nutrition and Physical Activity, 7(17). 


\section{OPENING NEIGHBOURHOOD STREETS FOR COMMUNITY-BUILDING AND CHILDREN'S OUTDOOR FREE PLAY}

Ravensbergen, L., Buliung, R., Wilson, K., Faulkner, G.E.J. (2016). Socioeconomic disparities in children's access to physical activity facilities: an activity space analysis. Trans. Res. Rec. 2598. http://dx.doi.org/10.3141/2598-02.

Read, J. (2011). Gutter to Garden: Historical Discourses of Risk in Interventions in Working Class Children's Street Play. Children \& Society 25(1), 421-434.

Reitsma-Street, M., Maczewski, M., \& Neysmith, S. (2000). Promoting engagement: An organizational study of volunteers in community resource centres for children. Children and Youth Services Review. 22(8). 651-678. https://doi.org/10.1016/S01907409(00)00106-7

Sallis, J., Nader, P., Broyles, S., Berry, C., Elder, J., McKenzie, T., Nelson, J. (1993). Correlates of physical activity at home in Mexican-American and Anglo-American preschool children. Health Psychology 12 (5), 390-398.

Seattle Department of Transportation (2016). Play Streets Program Briefing Report. www.seattle.gov/transportation

Seattle Department of Transportation (2017). Play Streets. http://www.seattle.gov/transportation/ projects-and-programs/programs/public-space-management-programs/playstreets\#playstreetsvideo tutorials

Semenza, J., \& March, T. (2008). An Urban Community-Based Intervention to Advance Social Interactions. Environment and Behavior, 41(1), p. 22-42

Singer, D., Singer, J., D’Agostino, H., \& DeLong, R. (2009). Children's pastimes and play in sixteen nations: Is free-play declining? American Journal of Play, 1, 283-312.

Smale, B. (2010). Leisure and Culture: A Report of the Canadian Index of Wellbeing (CIW). Institute of Wellbeing. Toronto ON: Canadian Index of Wellbeing.

Tandy, C. (1999). Children's diminishing play space: a study of inter-generational change in children's use of their neighbourhoods. Australian Geographical Studies 37 (2), 154-164.

Timperio, A., Crawford, D., Telford, A., Salmon, J., (2004). Perceptions of the local neighborhood and walking and cycling among children. Preventive Medicine 38 (1), 3947.

University of Waterloo (2016). How are Canadians really doing? The 2016 CIW National Report. Waterloo ON: Canadian Index of Wellbeing and University of Waterloo.

Valentine, G. \& McKendrick, J. (1997). Children's outdoor play: Exploring parental concerns about children's safety and the changing nature of childhood. Geoforum, 28 (2), 219-235.

Valentine, G. and McKendrick,J. (1998). 'Critical review: children's outdoor play: exploring parental concerns about children's safety and the changing nature of childhood', Geoforum, 28, 219-35.

Veitch, J., Bagley, S., Ball, K., and Salmon, J. (2006). Where do children usually play? A qualitative study of parents' perceptions of influences on children's active free-play, Health \& Place, Volume 12, Issue 4, Pages 383-393, ISSN 1353-8292 https://doi.org/10.1016/j.healthplace.2005.02.009.

Veitch, J., Salmon J, Ball K. (2007). Children's Perceptions of the Use of Public Open Spaces for Active Free-play. Child Geogr. 5: 409-422.

Villanueva, K., Giles-Corti, B., Bulsara, M., Timperio, A., McCormack, G., Beesley, B., Middleton, N. (2013). Where do children travel to and what local opportunities are available? the relationship between neighborhood destinations and Children's independent mobility. Environment and Behavior, 45(6), 679-705.

$10.1177 / 0013916512440705$ 


\section{OPENING NEIGHBOURHOOD STREETS FOR COMMUNITY-BUILDING AND CHILDREN'S OUTDOOR FREE PLAY}

Weller, S., \& Bruegel, I. (2009). Children's 'Place' in the development of neighbourhood social capital. Urban Studies, 46(3), 629-643.

Wilson, W. J. (1996). When Work Disappears: The World of the New Urban Poor. New York: Knopf.

Witten, K., Kearns, R., \& Carroll, P. (2015). Urban inclusion as wellbeing: Exploring children's accounts of confronting diversity on inner city streets. Social Science \& Medicine, 133: 349-357. 10.1016/j.socscimed.2015.01.016

Wood, J. (2017) Planning for children's play: exploring the 'forgotten' right in Welsh and Scottish policy. The Town Planning Review; Liverpool. 88 (5): 579-602.

Zeif, S., Chaudhuri, A. \& International Journal of Play Musselman, E. (2016). Creating neighbourhood recreational space for youth and children in the urban environment: Play (ing in the) Streets in San Francisco, Children and Youth Services Review 70: 95- 101.

Zieff, $G$ et al. (2016). Creating neighborhood recreational space for youth and children in the urban environment: Play(ing in the) Streets in San Francisco . Children and Youth Services Review 70, 95-101. 